\title{
NPY Gene Product
}

National Cancer Institute

\section{Source}

National Cancer Institute. NPY Gene Product. NCI Thesaurus. Code C136720.

A protein encoded by the NPY gene. 